\section{Preservation of Wild Animals in Asia}

Muci has been written in recent years on the threat of extermination hanging over much of the fauna of Africa and on possible methods of averting it. Less has been heard about the equally pressing danger to the fauna of other parts of the world. The timely appearance of a report on some animals of the Middle East and southern Asia which are threatened with extermination entitled "A Look at Threatened Species", by L. M. Talbot (Oryx, the Journal of the Fauna Preservation Society, 5, Nos. 4 and 5, I57; May 1960), is therefore particularly wolcomo. The report is based on information collected during an extensive journey of reconnaissance in 1955 extending from Libya to Formosa. The investigation was concerned principally with the past and present status of the three species of Asiatic rhinoceros, the Indian lion, the Arabian oryx, and the Syrian wild ass; but the report also deals with many other species. It is a most interesting and well-written document that considers in some detail such matters as wild-life habitats and land-use, and gives an account of such reserves and parks as there are in the territories visited. One of the largest problems facing conservation is the lack of trained personnel. In most former 'Colonial' territories conservation and management were carried out by men from the colonizing country. When they departed, the country was left with very fow people with any training at all in conservation matters. Nevertheless, although in many places there has been, and still is, much wanton destruction, a real effort is being made in others at conserving what is left. This report will strengthen the hand of the International Union for the Conservation of Nature in its efforts to help those concerned in preventing the final extermination of a number of interesting specios of animals.

\section{Geomorphological Abstracts}

As a guide to the very scattered literature of interest to geomorphologists, a small journal of abstracts, in an attractive format, has recently been produced by a group of British geographers. In the first two numbers, for June and September 1960, abstracts are given of 136 recent papers, mainly works in English-language periodicals (No. 1 ; June 1960. Pp. 23. Published four times a year in March, June, September and December). At present some 120 journals are covered, and it is hoped to increase this number as circumstances permit. Geomorphological Abstracts will be published quarterly, and can be obtained from K. M. Clayton, Department of Geography, London School of Economics, Houghton Street, London, W.C.2, price 16s. per annum, post paid.

\section{Canadian Museum Publications}

The National Museum of Canada has added to its guide-books two publications which should be well received by visitors to the Museum. The first, "Canadian Atlantic Sea Shells", by E. L. Bousfield, is an illustrated account in English of sholl-bearing invertebrate animals commonly encountered on the beaches or in shallow waters of the Canadian Atlantic coast from the Strait of Belle Isle and the St. Law. rence estuary on the north to the ocean coasts of Newfoundland and Nova Scotia and the Bay of Fundy in the south. Altogether, 150 sea shells are described (Pp. v +72, 13 plates. Ottawa: Queen's Printer, 1960. 1 dollar). The second, "Les Mammi- fères du Canada", by Austin W. Cameron, contains descriptions in French of the mammals of Canada, each description being accompanied by a line drawing prepared by John Crosby (Pp. 89. Ottawa : Queen's Printer, 1960. 50 cents).

\section{Scientific Instrument Manufacturers' Association}

The Scientific Instrument Manufacturers' Associa. tion has published a booklet, "Careers in the Scientific Instrument Industry", providing a well-illustrated summary of what a new entrant into the industry can expect to find and what his work and training may be like (Pp. 20. London: Scientific Instrument Manufacturers' Association of Great Britain, 1960). The launching of the booklet has been encouraged by the rapidly increasing number of apprenticeship certificates issued by the Association's members under their endorsement scheme in recent years. In 1958, 52 certificates were endorsed, 64 in 1959 , and 82 in the first nine months of 1960 , or at a rate double that of 1958. The endorsement ensures that certain standards of training with the appropriate equipment are the foundation of the apprentice's certificate, and provide him with the start to a career in the scientific instrument manufacturing industry. The booklet can be obtained from the Scientific Instrument Manufacturers' Association, 20 Queen Anne Street, London, W.1.

\section{Information on Atomic Energy in Britain}

UNDER the title "A Guide to Information on Atomic Energy in Britain", the Central Office of Information has issued an illustrated select list of British books, periodicals, reports, films, photographs and display materials, describing the latest nuclear developments in the United Kingdom, which was originally compiled for specialized and prestige distribution overseas (Pp. 64. London: H.M. Stationery Office, 1960. $5 s$. net). The list was prepared with the co-operation of the United Kingdom Atomic Energy Authority. The material is arranged under visual aids ; general publications; serial publications; the power programme and nuclear engineering; radioisotopes; nuclear physics; and radiation hazards and protection. Books for the specialist and for the general reader are distinguished. There are also further lists of the Atomic Energy Authority's unclassified publications (including a list of depository libraries in the United Kingdom), and of publications covering legislation in the United Kingdom and co-operation with other countries.

\section{Restoration of a Silk Flag}

THE Museums Journal of November, in an article by Mr. Harry Wandrus, describes an economical method for the treatment of deteriorating silk flags. The flags were the property of the State of Ohio and most of them were of 'weighted' silk, that is, they contained chlorides or sulphates of magnesium, tin, iron or aluminium. Unfortunately, these chemicals have the effect of causing an early deterioration of the silk, which then crumbles and powders. The essence of the process is to soften the old flag with water and carefully assemble the parts in their correct positions on a flat table ready for a white silk chiffon backing. This backing should be neatly arranged over the flag and fastened with a 5 per cent solution of polyvinyl alcohol. The flag will then hang well in a vertical position. Full details of the process are given. 